\title{
Assessment of Iron Overload and Chelation Therapy in Adult In- patients with Sickle Cell Disease
}

\author{
Nicole Bohm ${ }^{1 *}$, Brittany Toussaint ${ }^{2}$, Stefanie Sarratt ${ }^{3}$, Leigh Vaughan ${ }^{4}$ and Ashley Duckett ${ }^{4}$ \\ ${ }^{1}$ Department of Clinical Pharmacy \& Outcome Sciences, Medical University of South Carolina, USA \\ ${ }^{2}$ Clinical Pharmacist, Emory University Hospital, USA \\ ${ }^{3}$ Department of Pharmacy, Spartanburg Medical Center, USA \\ ${ }^{4}$ Department of Medicine, Medical University of South Carolina, USA \\ *Corresponding author: Nicole Bohm, PharmD, Associate Professor, Department of Clinical Pharmacy \& Outcome Sciences, \\ Medical University of South Carolina, College of Pharmacy, 280 Calhoun St, QE205 MSC 140 Charleston, South Carolina 29425, \\ USA, Tel: 843-792-7523,E-mail:nmbohm@gmail.com; bohm@musc.edu
}

\begin{abstract}
Background: There is no consensus for the role of iron chelation therapy in patients with sickle cell disease receiving blood transfusions while hospitalized. The primary objective of this study was to assess the frequency of iron overload in adult inpatients with sickle cell disease and characterize the use of inpatient intravenous iron chelation therapy at the time of red blood cell transfusion. Secondary objectives were to describe the utilization of maintenance iron chelation therapies during hospital admissions and to develop a standardized approach to prescribing deferoxamine for this patient population at our institution.

Methods: This study was a retrospective cohort analysis of adult patients with sickle cell disease admitted to the general medicine service at a tertiary care academic medical center over a 26 -month period. Data were analyzed using descriptive statistics.

Results: Serum ferritin greater than $2,500 \mathrm{ng} / \mathrm{mL}$ was observed in 81/207 patients. Forty-seven patients were prescribed outpatient iron chelation. Deferoxamine was administered to 20 patients during 31 admissions; 6 were prescribed deferoxamine outpatient therapy and received their maintenance regimen during hospitalization. The remaining 14 patients received a median deferoxamine dose of $18 \mathrm{mg} / \mathrm{kg}$.

Conclusions: The prevalence of iron overload is high among hospitalized patients with sickle cell disease, but the use of inpatient iron chelators is variable. Based on observed practice, standardized deferoxamine doses could be beneficial for transfusional iron chelation.
\end{abstract}

\section{Keywords}

Sickle cell disease, Iron chelation, Deferoxamine, Ferritin

\section{Introduction}

Patients with sickle cell disease may require transfusions to increase hemoglobin, reduce the proportion of sickled red blood cells in circulation, and prevent complications such as stroke [1,2]. One unit of transfused packed Red Blood Cells (pRBC) contains 200-250 mg of elemental iron. Iron overload can develop after 10-20 transfusions, and deposition can lead to heart failure, hepatic fibrosis, and endocrine disorders. Iron overload is associated with significant morbidity in patients with sickle cell disease, with heart failure being identified as a major cause of mortality $[3,4]$.

Iron chelators complex with iron and facilitate excretion in the urine or feces $[5,6]$. The three approved iron chelators are deferoxamine (Desferal ${ }^{\circledR}$; DFO), deferasirox (Exjade ${ }^{\circledR}$ or Jadenu ${ }^{\mathrm{TM}}$; DFS), and deferiprone (Ferriprox $^{\oplus}$; DFP). Due to its short half-life and poor oral absorption, deferoxamine administered intravenously or subcutaneously is infused over 8 to 12 hours or continuously for 5 to 7 days per week [7]. Deferasirox and deferiprone are taken orally once or thrice daily, respectively, which may improve ease of administration [8-11]. The newest formulation of deferasirox can be administered without regard to food and does not require dispersion in liquid [10].

The National Institutes of Health (NIH) recommends

Citation: Bohm N, Toussaint B, Sarratt S, Vaughan L, Duckett A (2018) Assessment of Iron Overload and Chelation Therapy in Adult Inpatients with Sickle Cell Disease. Int Arch Clin Pharmacol 4:014. doi. org/10.23937/2572-3987.1510014

Received: March 27, 2017: Accepted: March 22, 2018: Published: March 24, 2018

Copyright: (c) 2018 Bohm N, et al. This is an open-access article distributed under the terms of the Creative Commons Attribution License, which permits unrestricted use, distribution, and reproduction in any medium, provided the original author and source are credited. 
Table 1: Patient characteristics and DFO use.

\begin{tabular}{|c|c|c|}
\hline Inpatient Use of DFO & $\begin{array}{l}\text { DFO } \\
(n=21)\end{array}$ & $\begin{array}{l}\text { No DFO } \\
(n=187)\end{array}$ \\
\hline Serum ferritin, $\mathrm{ng} / \mathrm{mL}$ & $\begin{array}{l}8,873(6,115-10,978) \\
(n=20)\end{array}$ & $\begin{array}{l}2,019(747-5,226) \\
(n=136)\end{array}$ \\
\hline \multicolumn{3}{|l|}{ Serum ferritin, $n(\%)$} \\
\hline$<1,000 \mathrm{ng} / \mathrm{mL}$ & $1(5)$ & $41(30)$ \\
\hline $1,000-2,499 \mathrm{ng} / \mathrm{mL}$ & 0 & $33(24)$ \\
\hline $2,500-4,000 \mathrm{ng} / \mathrm{mL}$ & $2(10)$ & $14(10)$ \\
\hline$>4,000 \mathrm{ng} / \mathrm{mL}$ & $17(85)$ & $48(36)$ \\
\hline Blood transfusions during study, $\mathrm{mL} / \mathrm{kg}$ & $48(19-54)$ & $9(0-27)$ \\
\hline Patients on outpatient DFO & $(n=6)$ & $(n=7)$ \\
\hline Inpatient DFO dose, mg/kg & $82(55-90)$ & $\mathrm{n} / \mathrm{a}$ \\
\hline Number of doses, median (range) & $2(1-5)$ & $\mathrm{n} / \mathrm{a}$ \\
\hline Patients on outpatient DFS & $(n=8)$ & $(n=26)$ \\
\hline Inpatient DFO dose, mg/kg & $17(13-32)$ & $\mathrm{n} / \mathrm{a}$ \\
\hline Number of doses, median (range) & $1(1-7)$ & $\mathrm{n} / \mathrm{a}$ \\
\hline No outpatient chelation & $(n=6)$ & $(n=154)$ \\
\hline Inpatient DFO dose, mg/kg & $39(15-55)$ & $\mathrm{n} / \mathrm{a}$ \\
\hline Number of doses, median (range) & $1(1-2)$ & $n / a$ \\
\hline
\end{tabular}

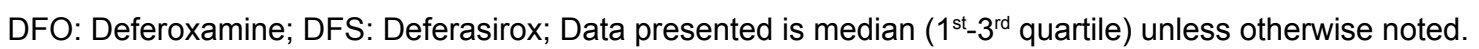

initiating chelation therapy for Liver Iron Concentrations (LIC) greater than $7 \mathrm{mg} / \mathrm{g}$ dry weight, cumulative transfusions of $120 \mathrm{~mL}$ of pure red cells per kilogram of body weight, or serum ferritin level greater than $1,000 \mathrm{ng} /$ $\mathrm{mL}$ [12]. Currently, there is no consensus for the role of chelation therapy in inpatients with iron overload, particularly those receiving blood transfusions while hospitalized. Therefore, this study was conducted to help provide insight into the current use of DFO for transfusion-related iron overload in patients with sickle cell disease at our institution.

\section{Methods}

This was a single-center, retrospective cohort study of adult patients with sickle cell disease admitted to the general medicine service over a 26-month period at a tertiary care academic medical center. The MUSC Institutional Review Board approved this study.

The primary objectives were to assess the frequency of transfusion-related iron overload in adults with sickle cell disease and evaluate the use of iron-chelating therapy at our institution. The secondary objectives were to develop and implement a DFO protocol for this patient population at our institution in order to standardize the utilization and dosing of DFO for transfusion-related iron overload in adult patients with sickle cell disease.

Patients were identified using the International Classification of Diseases (ICD) codes for sickle cell disease. Data collected from electronic medical record included demographics, length of stay, pRBC received, and outpatient and inpatient iron chelator use. The following laboratory values were recorded if available: Serum ferritin, serum iron, total iron binding capacity, serum creatinine, complete blood count, hemoglobin vari- ants, liver function tests, liver iron concentration, pertinent radiographic imaging results, and left ventricular ejection fraction. Data analysis was performed using descriptive statistics. For patients with multiple hospital admissions, the first available data point within the study period was used. When data distribution was not normal, median and IQR was reported.

\section{Results}

Two hundred and seven patients were included ( $\mathrm{Ta}$ ble 1 ). One hundred and twenty patients (58\%) were female and all patients were African American with an average age of 29 years. The average length of hospital stay was 6.2 days. Twenty patients received DFO therapy during 31 admissions. Iron overload, defined as a serum ferritin levels greater than $2,500 \mathrm{ng} / \mathrm{mL}$, occurred in 79 patients $(38 \%)$. One hundred and thirty patients (63\%) had an ICD code for iron overload. Among patients receiving at least one inpatient dose of DFO, median serum ferritin levels were $8,872 \mathrm{ng} / \mathrm{mL}\left(1^{\text {st }}-3^{\text {rd }}\right.$ quartile, 6,115-10,979). For patients that did not receive DFO, median serum ferritin levels were $5,312 \mathrm{ng} / \mathrm{mL}$ $(602-5,806)$.

Thirty-six patients $(17 \%)$ were prescribed outpatient oral chelation therapy with DFS and $13(6 \%)$ with DFO. Over half of patients receiving outpatient DFO did not receive iron chelation during hospitalization. Patients prescribed outpatient DFO therapy received higher inpatient doses compared to those not prescribed outpatient DFO therapy ( $82 \mathrm{mg} / \mathrm{kg}$ vs. $18 \mathrm{mg} / \mathrm{kg} /$ dose, respectively). Overall, 6 patients were prescribed chronic outpatient DFO therapy and subsequently received the same maintenance regimen during inpatient hospital admissions. The most frequently prescribed DFO doses were 1,000 and $2,000 \mathrm{mg}$, often ordered as a one-time dose administered 
post-transfusion. Transfusion of pRBC occurred during 323 admissions in 99 unique patients. The median volume of blood received was higher among patients who received inpatient DFO therapy compared to patients who did not receive inpatient $D F O[2,803 \mathrm{~mL}(1,000-3,910)$ and 1,310 $\mathrm{mL}(0-1,834)]$.

\section{Discussion}

At our institution, iron overload is very common among patients hospitalized with sickle cell disease and appears to be undertreated. Blood transfusions in these patients are common. The decision to administer inpatient DFO therapy in attempt to minimize the impact of blood transfusions on iron stores is patient- and prescriber-specific.
Many patients had significant iron overload with markedly elevated serum ferritin levels, presumably secondary to chronic transfusion therapy. However, we are unable to rule out other causes of hyperferritinemia in this patient population. Ferritin is an acute phase reactant that can be acutely elevated in the presence of liver dysfunction or inflammatory conditions such as vaso-occlusive crises or infection [13]. Nevertheless, it is predictive of mortality and correlates with LIC thought not necessarily cardiac iron [14-17]. The role of iron in hypercoagulability is an emerging area of importance [18]. The increased frequency of iron overload observed compared to a range of approximately $13 \%$ to $30 \%$ in other studies is notable $[19,20]$. We propose this may be a consequence of the

\section{DEFEROXAMINE (DESFERAL ${ }^{\circledR}$ ) \\ Adult Inpatient Order Form \\ For patients with sickle cell anemia receiving a simple transfusion}

Patient Weight: kg

\section{Indications:}

$\square$ Ferritin $>1,000 \mathrm{ng} / \mathrm{mL}$

\section{Relative Contraindications:}

$\square$ Severe renal disease or anuria

$\square$ Breast-feeding

$\square$ Pregnant

$\square$ Gallium-67 scintigraphy planned within 48 hours

$\square$ Suspected or known zygomycosis, Yersinia enterocolitica, or Yersinia pseudotuberculosis infection

*Consider temporary discontinuation of prochlorperazine due to reports of impaired consciousness

Dosing: Maximum recommended dose is $60 \mathrm{mg} / \mathrm{kg} / \mathrm{d}=$ $\mathrm{mg}$; reduce dose for $\mathrm{CrCl}<50 \mathrm{~mL} / \mathrm{min}$

1. Deferoxamine $\left(\right.$ Desferal $\left.{ }^{\circledR}\right)$ :

$\square 2000 \mathrm{mg}$ IV once after transfusion complete

$\square 1000 \mathrm{mg}$ IV once after transfusion complete

$\square 500 \mathrm{mg}$ IV once after transfusion complete

(round to nearest $500 \mathrm{mg}$ ) IV once after transfusion complete

2. Administration time (not to exceed $15 \mathrm{mg} / \mathrm{kg} / \mathrm{hr}$; minimum infusion time $=$ h (calculated):

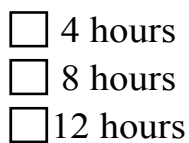

\section{Clinical Practice Points}

- Dosage adjustments

1. $\mathrm{CrCl} 10-50 \mathrm{~mL} / \mathrm{min}, \mathrm{CRRT}$ : Administer $25-50 \%$ of normal dose

2. $\mathrm{CrCl}<10 \mathrm{~mL} / \mathrm{min}, \mathrm{HD}, \mathrm{PD}$ : Consider alternative agent

- Each $1000 \mathrm{mg}$ dose of deferoxamine can chelate up to 85 to $95 \mathrm{mg}$ of elemental iron

- Each unit of pRBC contains approximately $200-250 \mathrm{mg}$ of elemental iron

Consider vitamin C supplementation up to $200 \mathrm{mg}$ po daily for patients receiving frequent doses for at least 1 month without cardiac dysfunction

Figure 1: Deferoxamine adult inpatient order form. 
patients included, who may have had a more symptomatic phenotype with increased VOC, hospitalizations, and transfusions. Despite the lack of evidence comparing steady state ferritin levels to those seen in acute hospitalization for this patient population, the degree of elevation seen in our patients suggests that total body iron stores are excessive, even in the setting of inflammatory states.

Given the broad range of dosing recommendations for DFO and lack of a specific protocol to guide prescribers, a wide range of DFO doses were prescribed. Theoretically, 1,000 mg of DFO can chelate up to 85 to $95 \mathrm{mg}$ of elemental iron [7]. Among treatment-naïve patients, or those not prescribed outpatient DFO therapies, doses of $1,000 \mathrm{mg}$ or $2,000 \mathrm{mg}$ were more commonly ordered. Patients prescribed DFO outpatient therapy were started on their maintenance DFO regimen while inpatient and, on average, received larger doses of DFO. Based on this variability, we proposed an inpatient order form to guide prescribers ordering DFO in patients with sickle cell disease receiving simple blood transfusions (Figure 1). Once the patient's body weight is entered, the dose and infusion rate are automatically calculated, and prescribers may then select an appropriate, rounded DFO dose. This will encourage prescribers to administer standardized DFO doses at the appropriate infusion rate to patients with elevated serum ferritin levels.

Records indicated a small percentage of patients were prescribed outpatient chelation therapy, and adherence rates are unknown. A retrospective evaluation of patients with sickle cell disease enrolled in Medicaid programs across 10 states in the US found discontinuation rates as high as $95 \%$ with DFO and $80 \%$ with DFS, after 18 months of treatment [21]. At our institution, patients that are prescribed outpatient DFS therapy are required to use their home supply while inpatient. Subsequently, patients do not receive DFS during their hospitalization if they fail to provide a home supply. Therefore, the implementation of an inpatient iron chelation protocol for patients requiring frequent hospitalizations may be particularly useful. The inpatient DFO order form will not only provide guidance in dosing, but also includes clinical pearls regarding relative contraindications and renal dosing recommendations.

We are unable to define a temporal relationship between DFO administration and changes in serum ferritin levels throughout the study period. Other limitations include the small cohort of patients who received inpatient DFO, the possibility of inappropriate ICD coding, and the inability to account for treatment received outside of our institution. It is possible that patients may have received blood transfusions and/or iron chelation therapy during admissions to outside hospitals. More aggressive inpatient chelation may be warranted for patients with frequent and/or prolonged hospitalizations in attempt to improve overall iron status but is beyond the scope of this study.
It is significant that compared to the reported rate of approximately $27 \%$ of patients admitted for vaso-occlusive crisis receiving transfusions nationally, the rate at our institution was much higher [22]. While this statistic requires further evaluation, without demographic and other disease severity data, it is not possible to further assess the implications. However, implementing guidelines for transfusions specific to patients with sickle cell disease could ensure uniform and appropriate transfusion strategies.

In conclusion, iron overload is very common among adult patients hospitalized with sickle cell disease at our institution and is undertreated. DFO is infrequently administered to treatment-naive patients. The implementation of a standardized DFO protocol is warranted to aid clinicians in the appropriate use and dosing of this agent. Additional data would be valuable to understand long-term outcomes and assess the implications of iron overload and its treatment in patients of varying race and nationality.

\section{References}

1. Brittenham GM (2011) Iron-Chelating Therapy for Transfusional Iron Overload. N Engl J Med 364: 146-156.

2. Fleming RE, Ponka P (2012) Iron overload in human disease. N Engl J Med 366: 348-359.

3. Andrews NC (1999) Disorders of iron metabolism. N Engl J Med 341: 1986-1995.

4. Inati A, Khoriaty E, Musallam KM, Taher AT (2010) Iron chelation therapy for patients with sickle cell disease and iron overload. Am J Hematol 85: 782-786.

5. Bring P, Partovi N, Ford JE, Yoshida EM (2008) Iron overload disorders: treatment options for patients refractory to or intolerant of phlebotomy. Pharmacotherapy 28: 331-342.

6. Cohen AR (2006) New advances in iron chelation therapy. Hematology Am Soc Hematol Educ Program 2006: 42-47.

7. Desferal (deferoxamine) prescribing information (2011) Novartis Pharmaceuticals Corporation, East Hanover, NJ.

8. Stumpf JL (2007) Deferasirox. Am J Health Syst Pharm 64: 606-616.

9. Exjade (deferasirox) prescribing information (2013) Novartis pharmaceuticals corporation, East Hanover, NJ.

10. Jadenu (deferasirox) prescribing information (2016) Novartis pharmaceuticals corporation, East Hanover, NJ.

11. Ferriprox (deferiprone) prescribing information (2012) Apotex Inc; Ontario, Canada.

12. National Heart, Lung, and Blood Institute, Division of Blood Diseases and Resources (2002) The Management of Sickle Cell Disease. National Institutes of Health. ( $4^{\text {th }}$ edn $), \mathrm{NIH}$ Publication 02-2117.

13. Wood JC (2014) Guidelines for quantifying iron overload. Hematology Am Soc Hematol Educ Program 1: 210-215.

14. Porter JB, El-Alfy M, Viprakasit V, Giraudier S, Chan LL, et al. (2016) Utility of labile plasma iron and transferrin saturation in addition to serum ferritin as iron overload markers in different underlying anemias before and after deferasirox treatment. Eur J Haematol 1: 19-26. 
15. Feld JJ, Kato GJ, Koh C, Shields T, Hildesheim M, et al. (2015) Liver injury is associated with mortality in sickle cell disease. Aliment Pharmacol Ther 42: 912-921.

16. Vitrano A, Calvaruso G, Tesé L, Gioia F, Cassarà $F$, et al. (2016) Real-life experience with liver iron concentration R2 MRI measurement in patients with hemoglobinopathies: baseline data from LICNET. Eur J Haematol 97: 361-370.

17. Badawy SM, Liem RI, Rigsby CK, Labotka RJ, DeFreitas RA, et al. (2016) Assessing cardiac and liver iron overload in chronically transfused patients with sickle cell disease. $\mathrm{Br}$ J Haematol 175: 705-713.

18. Shah N, Welsby IJ, Fielder MA, Jacobsen WK, Nielsen VG (2015) Sickle cell disease is associated with iron mediated hypercoagulability. J Thromb Thrombolysis 40: 182-185.

19. Darbari DS, Kple-Faget P, Kwagyan J, Rana S, Gordeuk
VR, et al. (2006) Circumstances of death in adult sickle cell disease patients. Am J Hematol 81: 858-863.

20. Pack-Mabien A, Brown B, Herbert DE, Haynes J Jr (2015) Iron overload in adults with sickle cell disease who have received intermittent red blood cell transfusions. J Am Assoc Nurse Pract 27: 591-596.

21. Armstrong EP, Skrepnek GH, Sasane M, Snodgrass SM, Ballas SK (2013) Long-term persistency and costs associated with the use of iron chelation therapies in the treatment of sickle cell disease within Medicaid programs. J Med Econ 16: 10-18.

22. Telen MJ, Afenyi-Annan A, Garrett ME, Combs MR, Orrigner EP, et al. (2015) Alloimmunization in sickle cell disease: changing antibody specificities and association with chronic pain and decreased survival. Transfusion 55: 1378-1387. 